BMJ Nutrition,

Prevention \& Health

\section{Vitamin C and alcohol: a call to action}

${ }^{1}$ Adelaide Medical School, University of Adelaide, Adelaide, South Australia, Australia ${ }^{2}$ Department of General Medicine, Flinders Medical Centre, Bedford Park, South Australia, Australia

${ }^{3}$ Discipline of Medicine, University of Adelaide, Adelaide, South Australia, Australia

Correspondence to Daniel James Lim, Adelaide Medical School, University of Adelaide, Adelaide, SA 5005,

Australia; danlimjre@gmail.com

Received 25 September 2018 Revised 24 October 2018 Accepted 1 November 2018 Published Online First 5 December 2018
A) Check for updates

(c) Author(s) (or their employer(s)) 2018. Re-use permitted under CC BY-NC. No commercial re-use. See rights and permissions. Published by BMJ.

To cite: Lim DJ, Sharma Y, Thompson CH. bmjnph 2018;1:17-22.

\section{INTRODUCTION}

Vitamin C, an essential water-soluble nutrient that cannot be synthesised by humans, has a role in numerous biological reactions. ${ }^{1}$ It is necessary for enzymatic reactions and biosynthesis of hormones, ${ }^{2}$ and protects biomolecules through its antioxidant properties. ${ }^{1}$ Critical in the biosynthesis of collagen, it is crucial in preserving essential tissue structure and function, without which capillary fragility develops. $^{12}$

While its biological function has been well proven, its therapeutic utility has been well contested over the years. The initial hope of a positive association between vitamin $\mathrm{C}$ status and health from several large cohort trials ${ }^{3-5}$ was quashed by results from large randomised controlled trials (RCTs) that did not find significant positive effects of vitamin C supplementation, when mortality or morbidity were set as endpoints. ${ }^{6-8}$ A review by Lykkesfeldt and Poulsen ${ }^{9}$ remarked this to be a result of a non-specific approach to examining the isolated effect of vitamin $\mathrm{C}$, and lamented a lack of subpopulation definition in the trials. However, the subsequent shift in the public's and health authorities' interests has left a gaping hole in evidence regarding vitamin $\mathrm{C}$ replacement.

Chronic alcoholism, on the other hand, remains a significant and widespread public health issue, wherebya recentglobal studyfound alcohol to be the seventh leading risk factor for death and disability-adjusted life-years. ${ }^{10}$
Table 1 Case reports on vitamin C deficiency and chronic alcohol intake

\begin{tabular}{|c|c|c|c|c|c|c|c|c|c|c|}
\hline \multirow[b]{2}{*}{ Reference } & \multirow[b]{2}{*}{ Country } & \multirow[b]{2}{*}{ Sex } & \multirow[b]{2}{*}{ Age } & \multirow[b]{2}{*}{ Clinical signs } & \multirow{2}{*}{$\begin{array}{l}\text { Alcohol } \\
\text { intake } \\
\text { (drinks/ } \\
\text { day) }\end{array}$} & \multirow{2}{*}{$\begin{array}{l}\text { Plasma } \\
\text { vitamin C } \\
(\mu \mathrm{mol} / \mathrm{L}) \\
\text { (RR 28-70) }\end{array}$} & \multirow[b]{2}{*}{$\begin{array}{l}\text { Other } \\
\text { deficiencies }\end{array}$} & \multicolumn{3}{|c|}{ Replacement regimen } \\
\hline & & & & & & & & $\begin{array}{l}\text { Vitamin } \\
\text { C/day } \\
\text { (mg) }\end{array}$ & Route & Period \\
\hline $\begin{array}{l}\text { Chaudhry } \\
\text { et } a l^{11}\end{array}$ & England & Male & 44 & $\begin{array}{l}\text { Lethargy,FH, } \\
\mathrm{PH}, \mathrm{G}\end{array}$ & Chronic & $<3$ & NS & 800 & Oral & $\begin{array}{l}2 \\
\text { weeks }\end{array}$ \\
\hline \multirow{2}{*}{$\begin{array}{l}\text { Wang and } \\
\text { Still }^{12}\end{array}$} & \multirow[t]{2}{*}{ USA } & \multirow[t]{2}{*}{ Male } & \multirow[t]{2}{*}{65} & \multirow[t]{2}{*}{$\mathrm{E}, \mathrm{PH}, \mathrm{G}, \mathrm{CH}$} & \multirow[t]{2}{*}{$10-15$} & \multirow[t]{2}{*}{6.82} & \multirow[t]{2}{*}{ NS } & 1000 & NS & 5 days \\
\hline & & & & & & & & 500 & NS & $\begin{array}{l}\text { After } 5 \\
\text { days }\end{array}$ \\
\hline Léger $^{13}$ & Canada & Male & 47 & $\begin{array}{l}\text { Lethargy, E, } \\
\text { PH }\end{array}$ & $8-10$ & $<10$ & NS & NS & Oral & NS \\
\hline $\begin{array}{l}\text { Takeshima } \\
\text { et a }\left.\right|^{14}\end{array}$ & Japan & Male & 45 & $\mathrm{P}, \mathrm{G}, \mathrm{Oe}$ & 13 & 1.13 & $\begin{array}{l}\text { Vit } B_{9}: 1.3 \\
\mathrm{ng} / \mathrm{mL}(\mathrm{RR} \\
2.4-12.0) \\
\mathrm{Hb}: 58 \mathrm{~g} / \mathrm{L} \\
(>135)\end{array}$ & 1200 & Oral & $\begin{array}{l}3 \\
\text { weeks }\end{array}$ \\
\hline \multirow{2}{*}{$\begin{array}{l}\text { Gião } \\
\text { Antunes et } \\
a^{15}\end{array}$} & \multirow[t]{2}{*}{ Portugal } & \multirow[t]{2}{*}{ Male } & \multirow[t]{2}{*}{40} & \multirow[t]{2}{*}{$\mathrm{GH}, \mathrm{FH}, \mathrm{PO}$} & \multirow[t]{2}{*}{12} & \multirow[t]{2}{*}{7.95} & \multirow{2}{*}{$\begin{array}{l}\text { Vit } B_{9}: 2.1 \\
\text { ng/mL (RR } \\
2.4-12.0) \\
\text { Hb: } 71 \mathrm{~g} / \mathrm{L} \\
(>135)\end{array}$} & 300 & Oral & $\begin{array}{l}2 \\
\text { weeks }\end{array}$ \\
\hline & & & & & & & & 100 & Oral & $\begin{array}{l}1 \\
\text { month } \\
\text { after } 2 \\
\text { weeks }\end{array}$ \\
\hline \multirow{3}{*}{$\begin{array}{l}\text { Lux- } \\
\text { Battistelli } \\
\text { and } \\
\text { Battistelli }^{16}\end{array}$} & \multirow[t]{3}{*}{ USA } & Male & 54 & $\begin{array}{l}\text { Lethargy, } \\
\text { weak, P, GH }\end{array}$ & Dependent & 3.1 & NS & 1000 & Oral & $\begin{array}{l}8-10 \\
\text { weeks }\end{array}$ \\
\hline & & Male & 24 & $\begin{array}{l}\text { Fatigue, weak, } \\
\text { dyspnoea, Oe }\end{array}$ & $14-28$ & $<3$ & NS & 1000 & Oral & $\begin{array}{l}12 \\
\text { weeks }\end{array}$ \\
\hline & & Male & 48 & $\mathrm{FH}$, unsteady & 34 & $<24$ & NS & 500 & Oral & $\begin{array}{l}12 \\
\text { weeks }\end{array}$ \\
\hline $\begin{array}{l}\text { Bennett et } \\
a l^{17}\end{array}$ & USA & Male & 64 & $\begin{array}{l}\mathrm{E}, \mathrm{GH} \text {, } \\
\text { unsteady } \\
\text { weight loss }\end{array}$ & $8-10$ & 5.68 & $\begin{array}{l}\text { Vit } B_{9}: 2 \mathrm{ng} / \mathrm{mL} \\
(R R>4.7) \\
\text { Vit } B_{6}:<2 \mu \mathrm{g} / \mathrm{L} \\
(\text { RR } 5-50)\end{array}$ & NS & Oral & NS \\
\hline
\end{tabular}

$\mathrm{CH}$, corkscrew hairs; $\mathrm{E}$, ecchymoses; FH, follicular hyperkeratosis; G, gingivitis; GH, gingival hypertrophy; Hb, haemoglobin; NS, not specified; Oe, oedema; $\mathrm{P}$, petechiae or purpura; $\mathrm{PH}$, perifollicular haemorrhages; $\mathrm{PO}$, periodontitis; RR, reference range; Vit, vitamin. 
There has been no lack of case reports documenting florid scurvy in chronic alcoholics, ${ }^{11-17}$ yet the mechanistic links between hypovitaminosis $\mathrm{C}$ and chronic alcoholism remain postulations based on research from the early 1980s. Furthermore, replacement regimens and routes remain far from standardised, as evidenced by the varied treatment approaches in these reports (table 1).

As such, the present review examines the current and past knowledge on vitamin $\mathrm{C}$ deficiency and its role in chronic alcoholics, evaluates the current guidelines on alcohol withdrawal, and provides suggestions and exhortation for future trials. PubMed, MEDLINE and Current Contents (1960-2018) were searched using medical subject headings and free text with a combination of the following terms: vitamin $\mathrm{C}$, vitamin $\mathrm{C}$ deficiency, ascorbic acid, scurvy, alcohol, chronic alcoholic and alcohol withdrawal guidelines. Original articles, contemporary reviews, case reports and international guidelines were used.

\section{Clinical significance of vitamin C deficiency}

The prevalence of hypovitaminosis varies across the world; however, it has been observed to be higher in hospitalised patients. ${ }^{18}$ The current definition of optimal vitamin $\mathrm{C}$ status, while controversial, has been based on a dietary intake that results in a plasma concentration of approximately $70 \mu \mathrm{mol} / \mathrm{L}$ in an otherwise healthy person. ${ }^{19}$ The recommended daily allowance for vitamin $\mathrm{C}$ has been stated at $75 \mathrm{mg} /$ day for women and $90 \mathrm{mg} /$ day for men in the USA ${ }^{19}$; however, its uptake is highly dose-dependent and varies depending on saturation from daily diet.

Furthermore, the extensive variability of plasma vitamin $\mathrm{C}$ levels to clinical signs has prompted the definition of hypovitaminosis $\mathrm{C}$ with arbitrary cut-offs. Severe vitamin C deficiency has been proposed to be at a serum level of $<11 \mu \mathrm{mol} / \mathrm{L},{ }^{20}$ while marginal vitamin $\mathrm{C}$ deficiency is suggested as serum levels of $>11 \mu \mathrm{mol} / \mathrm{L}$ to $28 \mu \mathrm{mol} / \mathrm{L}{ }^{20}$

Scurvy, the clinical hallmark of severe vitamin C deficiency, is often the red flag that alerts the clinician to measure plasma vitamin $\mathrm{C}$ levels. It manifests primarily as capillary haemorrhages, gingivitis, lassitude and muscle weakness. ${ }^{11-17}$ Apart from scurvy, severe vitamin C deficiency has been shown to increase the relative risk of myocardial infarction, ${ }^{5}$ while marginal vitamin $\mathrm{C}$ deficiency has also been shown to be significantly associated with all-cause mortality, with weak associations with death from cancer. ${ }^{4}$

Despite the significant progress being made in the clinical significance of hypovitaminosis $\mathrm{C}$, little is known about its role or replacement in chronic alcoholics.

\section{The case for vitamin C deficiency and alcohol}

Excessive alcohol consumption ( $>80 \mathrm{~g} /$ day) has been identified as one of the many risk factors for scurvy. ${ }^{18}$ This has traditionally been thought to be due to malnutrition with poor living conditions, leading to multiple nutritional deficiencies, especially vitamin $\mathrm{B}_{1}$ (thiamine) deficiency, associated with Wernicke-Korsakoff syndrome,

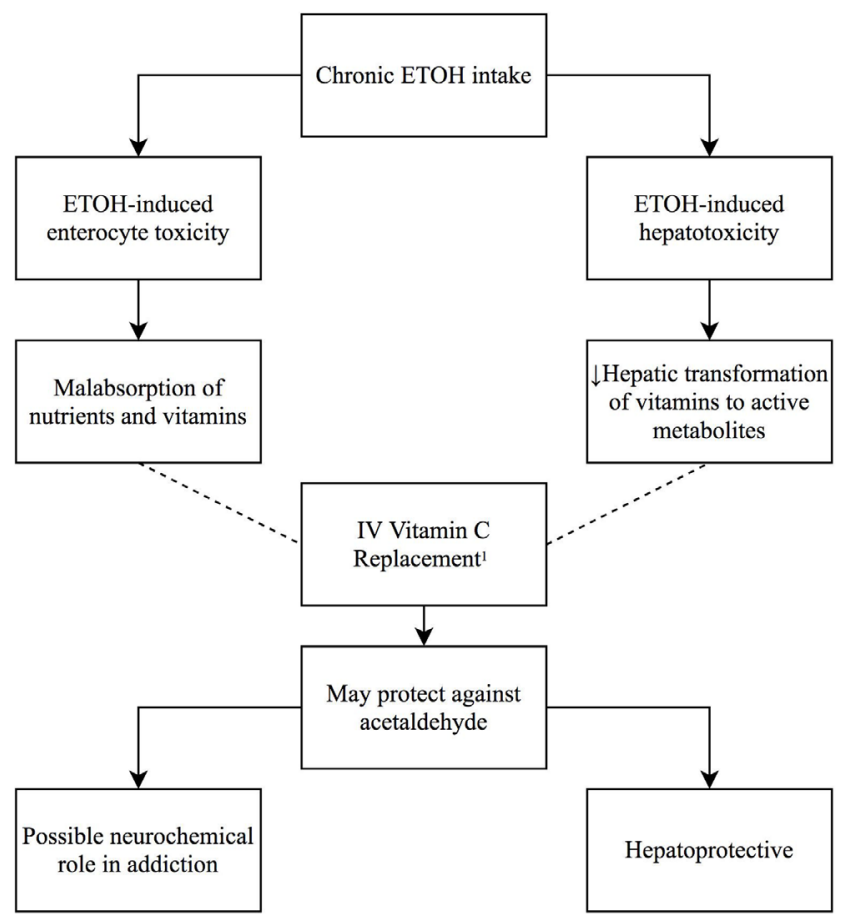

Figure 1 Postulated mechanisms of chronic alcohol intake and vitamin $\mathrm{C}$ replacement. ${ }^{1}$ Majumdar et al. $.^{22}----$, Prevents; ETOH, ethanol/alcohol.

and vitamin $\mathrm{B}_{3}$ (niacin) deficiency, associated with pellagra. ${ }^{11-17}$ However, as early as 1978, in a cohort of 35 patients with alcohol-related illness, Baines ${ }^{21}$ reported the incidence of vitamin C deficiency to be $91 \%$, compared with that of vitamin $B_{1}$ deficiency reported at $31 \%$. Since then, studies from the 1980s have shown that hypovitaminosis $\mathrm{C}$ alone is likely to have a significant effect on chronic alcohol use and vice versa. However, there has since been a lack of follow-up on these key findings that may play a significant role in the detoxification or withdrawal regimen of the chronic alcoholic.

In 1981, Majumdar et $a l^{22}$ found that short-term intravenous vitamin $\mathrm{C}$ supplementation $(500 \mathrm{mg}$ mane for 5 days) in chronic alcoholics with hypovitaminosis $\mathrm{C}$ improved serum levels of vitamin C significantly, but in 16 of 25 patients they did not return to normal ranges. This was consistent with previous studies, where it took up to 3 months of oral vitamin $\mathrm{C}$ supplementation for blood levels to return to normal in chronic alcoholics. ${ }^{23}$

Thus, Majumdar and colleagues ${ }^{22}$ postulated that ethanol-induced enterocyte toxicity induces intestinal malabsorption of vitamins, while ethanol-induced hepatotoxicity results in insufficient hepatic transformation of many vitamins to their active metabolites ${ }^{22}$ (figure 1 ). They also suggested that vitamin $\mathrm{C}$ may be protective against toxic effects of acetaldehyde, as proven in animal studies. ${ }^{24}$ This may reduce hepatotoxicity and possibly the biochemical basis of addiction, given acetaldehyde's action in dopaminergic stimulation of opiate receptors in the brain. ${ }^{22}$ However, given the low number of patients $(n=25)$ in their study, the likelihood of insufficient power, 

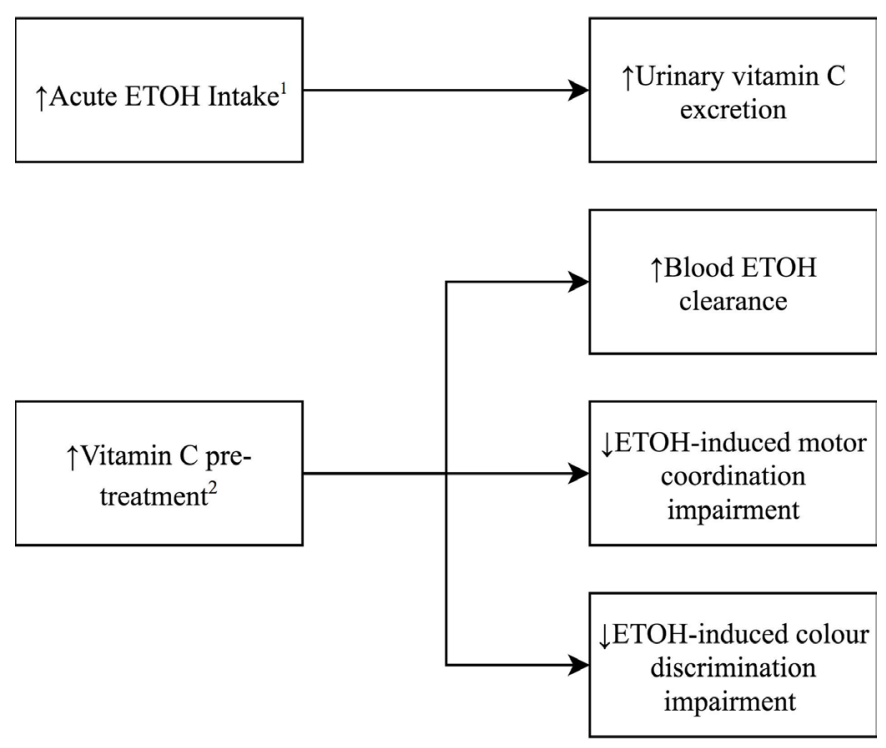

Figure 2 Study findings of acute alcohol intake and vitamin C. ${ }^{1}$ Faizallah et al. ${ }^{26}{ }^{2}$ Susick and Zannoni. ${ }^{27} \mathrm{ETOH}$, ethanol/ alcohol.

and therefore a false-negative finding, was high, requiring further large trials to confirm such results.

Since then, research looking at isolated vitamin C replacement in chronic alcoholism has been sporadic, barring a recent breakthrough showing decreased vitamin $\mathrm{C}$ uptake in pancreatic acinar cells of chronic alcoholics. ${ }^{25}$

The relationship between acute alcohol consumption and vitamin $\mathrm{C}$ deficiency has received more interest during the same time period (figure 2). Alcohol consumption of up to $0.58 \mathrm{~g}$ ethanol $/ \mathrm{kg}$ of body weight as whisky/ lager was shown, in 1986, to produce a $47 \%$ increase in urinary ascorbic acid excretion, compared with controls who drank nothing. ${ }^{26}$ Thereafter, a robust study by Susick and Zannoni ${ }^{27}$ in 1987 showed that vitamin C pretreatment (5 g daily for 2 weeks) significantly enhanced blood ethanol clearance, suggesting a contributory role of vitamin $\mathrm{C}$ to ethanol oxidation. These findings were bolstered by Chen et $a t^{28}$ in 1990 showing significantly increased plasma alcohol clearance following both shortterm and long-term vitamin $\mathrm{C}$ pretreatment.

Susick and Zannoni's ${ }^{27}$ study also looked at behavioural measures, finding that pretreatment resulted in significantly less ethanol-induced impairment of motor coordination and colour discrimination by $>20 \%$, as compared with placebo. ${ }^{27}$ These findings support a neurochemical role for the vitamin, as previously suggested by Majumdar et $a l^{22}$

While these studies were important, the populations looked at were healthy, unlike those of chronic alcohol use.

\section{Present-day guidelines and attitudes}

Given the strong bidirectional, and possibly therapeutic, link between vitamin $\mathrm{C}$ treatment and alcohol consumption, one would have expected a push for trials looking at vitamin $\mathrm{C}$ supplementation in chronic alcoholics. However, to date, vitamin $\mathrm{C}$ supplementation has only been proven to ameliorate ethanol-induced hepatotoxicity in mice, ${ }^{29}$ not humans, while RCTs, as stated above ${ }^{6-8}$ have not looked into the at-risk subpopulation of chronic alcoholic use. This is manifested in the present-day guidelines on alcohol withdrawal which provide scant instruction on vitamin $\mathrm{C}$ supplementation regimen or route (table 2 ).

The WHO guidelines for withdrawal state in a single line 'Multivitamin supplements and particularly vitamin B1 (thiamine) supplements (at least $100 \mathrm{mg}$ daily during withdrawal) should also be provided, ${ }^{30}$ while yet another international guideline, published in 2017 by the World Federation of Societies of Biological Psychiatry, makes mention of the state of hypovitaminosis in the alcoholic, but none to vitamin $\mathrm{C}$ or its replacement. ${ }^{31}$

Guidelines from multiple task forces across the United States of America (USA) make no mention at all of vitamin C replacement despite a known 'state of hypovitaminosis' in alcoholics, ${ }^{32} 33$ while Australian guidelines provide brief instruction, such as 'oral multivitamin preparation can be given to nutritionally depleted patients for several days'; however, there is no graded recommendation nor evaluation of the evidence. ${ }^{3435}$

While in the United Kingdom (UK), although national guidelines do not address hypovitaminosis C, ${ }^{36}$ local guidelines of various National Health Service Foundation Trusts ${ }^{37-39}$ both identify hypovitaminosis and specifically mention intravenous replacement of vitamin B and C acutely, although in the setting of Wernicke's encephalopathy. Encouragingly, they mention parenteral vitamin supplementation acutely, followed by oral supplementation. The lack of specificity, however, given that vitamin $\mathrm{C}$ is delivered adjunctively in an ampoule combined with vitamin $\mathrm{B}$, makes it difficult to investigate the isolated therapeutic value of vitamin $\mathrm{C}$ replacement.

Given the lack of evidence, promising RCT findings or even trials regarding vitamin $\mathrm{C}$ supplementation in chronic alcoholics, it comes as no surprise that major guidelines to date have not looked beyond the specifics of vitamin $B_{1}$ and $B_{12}$ replacement regimens. It seems the once-gilded promise of vitamin C's antioxidant value has lost its shine.

Yet it may be judicious to heed recommendations of past studies. Majumdar et $a l^{22}$ on the basis of their findings, advised nearly 40 years ago to include prolonged replenishment of vitamin $\mathrm{C}$ in conventional detoxification therapy for ethanol withdrawal syndrome, preferably by the intravenous route, postulating that it is needed for the utilisation of other vitamins and nutrients as well. ${ }^{22}$ Today, we know this to be true, given that vitamin C, with its reducing and chelating properties, is known to be the most efficient enhancer of non-haem iron absorption. ${ }^{40}$

Given the immense therapeutic potential of vitamin C replacement and robust evidence from past studies, it seems that the current practice gap or guideline omission 
Table 2 International guidelines on alcohol withdrawal and vitamin C replacement

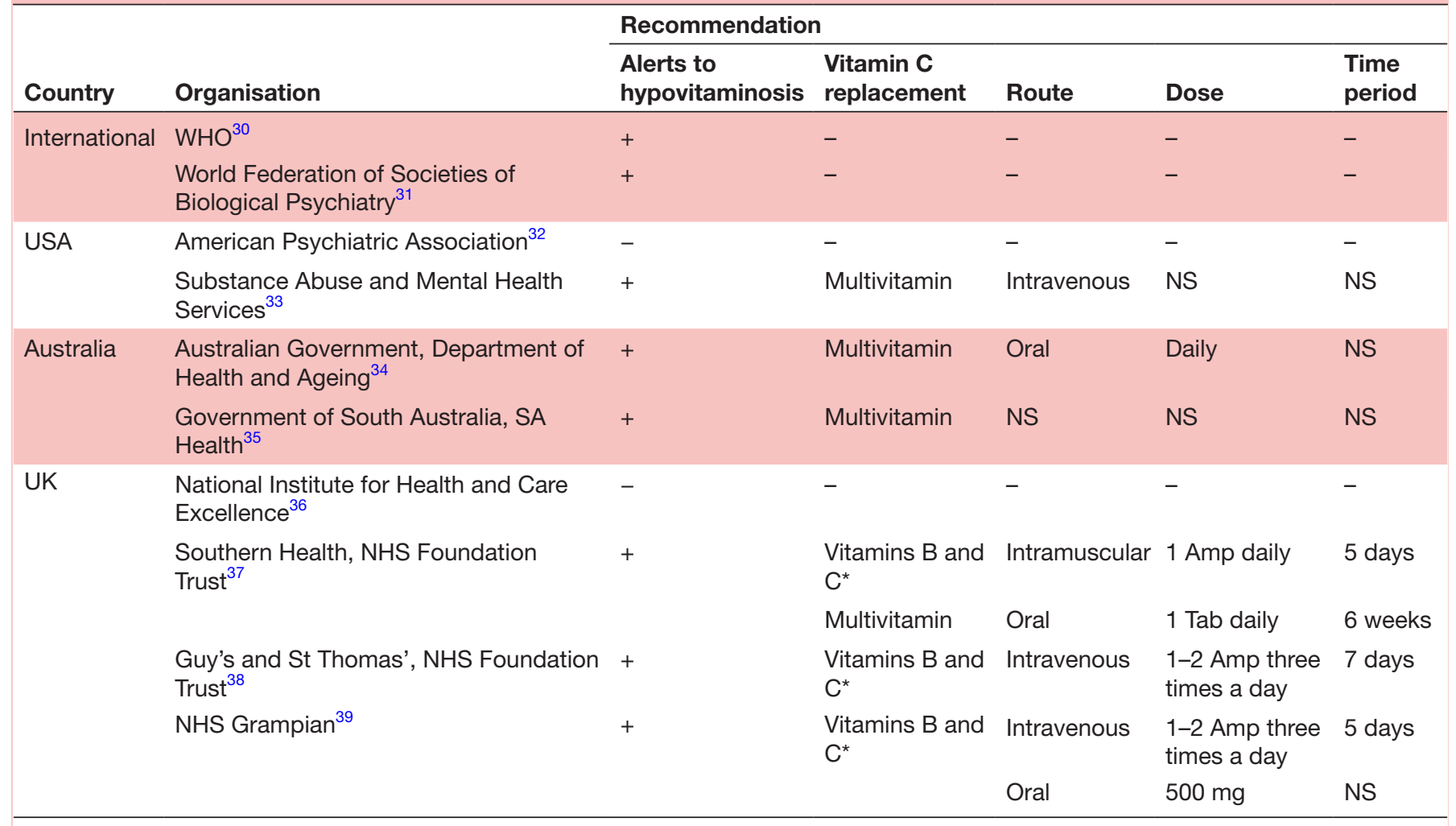

*Given as Pabrinex injection.

(+), present; (-), absent;Amp, ampoule (5 mL each); NS, not specified; Tab, tablet.

may stem from a non-targeted approach to the subpopulation of chronic alcoholics.

\section{Difficulties faced in populations with chronic alcohol use and recommendations for future studies}

There are multiple complexities faced when designing trials and studies for chronic alcoholics. Malnutrition, and its subsequent polyvitamin deficiency, is rampant in populations of chronic alcohol use, ${ }^{22}$ making it challenging to confer directionality to mechanistic hypotheses or isolate the effect of an intervention due to a single substance.

Given the association of inflammation and vitamin $\mathrm{C}$ deficiency, due to an increased tissue expenditure of nutrients, ${ }^{18}$ the systemic inflammatory response seen in chronic alcoholics with liver cirrhosis only adds another layer of complexity to any analysis. The subsequent loss of liver synthetic function also confers difficulty in interpreting whether clinical signs, such as widespread ecchymoses, are a result of a lack of vitamin $\mathrm{C}$ or coagulation factors, or both. ${ }^{11-17}$ In addition, progressive muscle weakness and gait unsteadiness in scurvy can mimic ethanol-induced cerebellar toxicity.

There also remain conflicting views concerning the necessity of vitamin C supplementation. A recent review by Flannery $e t a l,{ }^{41}$ on the management of alcohol-associated vitamin and electrolyte deficiencies, suggested providing routine supplementation of high-dose thiamine, magnesium sulfate and folic acid. They did not, however, recommend routine supplementation with vitamin $\mathrm{C}$, citing a lack of published data investigating the efficacy or safety of the acute use of multivitamin injection in patients with possible alcohol withdrawal. Despite this, they did remark that 'this lack of data does not necessarily negate the potential benefits of intravenous multivitamin in the acute setting,. ${ }^{41}$

After reviewing 35 RCTs with vitamin $\mathrm{C}$ as an intervention, Lykkesfeldt and Poulsen ${ }^{9}$ made the following suggestions for study parameters: hypovitaminosis $\mathrm{C}$ as an entry-level inclusion, verification of vitamin $\mathrm{C}$ levels at entry and during the study by a validated method, adjustment for confounders, a valid hypothesis or molecular mechanism involving vitamin $\mathrm{C}$ or mechanism-related hard clinical endpoint as a primary outcome, and explicit exclusion criteria. ${ }^{9}$

Targeting a subpopulation of chronic alcoholics, we suggest stratification of the quantity of alcohol intake and classification of severity of alcoholic liver disease, and adjusting for smoking status, socioeconomic status, dietary intake, quality of life, cognitive assessment, depression scale and acute illness, as vitamin C deficiency has been associated with these parameters. ${ }^{11-17}$

We suggest instituting vitamin $\mathrm{C}$ replacement intravenously with a specified regimen. This may be difficult to justify given the current lack of evidence for intravenous replacement, while juggling known risks, such as cannula site infection and hyperoxaluria, one of the side effects of high-dose vitamin $\mathrm{C}$ replacement. ${ }^{42}$ 
We therefore hope this review will serve as a call for more research, in particular for future RCTs to be designed with an inclusion criterion of hypovitaminosis $\mathrm{C}$ in a population affected by chronic alcohol use. The endpoints of such trials should include haematological, dermatological and hepatological clinical and laboratory measures (table 1) as surrogate markers for primary or secondary outcomes. This would provide the necessary evidence to further explore the optimal route and regimen of vitamin C replacement. Additionally, more observational studies are needed to evaluate the risk factors for hypovitaminosis $\mathrm{C}$ and its likelihood in patients of chronic alcohol exposure.

\section{CONCLUSION}

In conclusion, we have found a significant absence in the literature and published guidelines concerning vitamin C deficiency and chronic alcoholics. Given the substantial public health burden of chronic alcoholism, and the relatively inexpensive means of vitamin $\mathrm{C}$ replacement, we would like to call for an urgent response to the 'dire need to examine the effect of vitamin $\mathrm{C}$ as a single supplement in populations which have been carefully defined', as Lykkesfeldt and Poulsen ${ }^{9}$ so aptly adjudged. ${ }^{9}$ There is a need to build on, and to not forget, the insightful and robust evidence from the 1980s-1990s when developing trials and studies exploring the replacement of vitamin $\mathrm{C}$ deficiency in the chronic alcoholic, in order to review and further bolster current guidelines.

Contributors DJL engaged in the literature search, data collection for figures and tables, data analysis and interpretation, and supervised manuscript writing and revisions. YS analysed and interpreted the data and provided suggestions in drafting the manuscript. CHT engaged in the analysis and interpretation of data, data collection for figures and tables, and manuscript writing and revision.

Funding The authors have not declared a specific grant for this research from any funding agency in the public, commercial or not-for-profit sectors.

Competing interests None declared.

Patient consent for publication Not required.

Provenance and peer review Not commissioned; externally peer reviewed.

Open access This is an open access article distributed in accordance with the Creative Commons Attribution Non Commercial (CC BY-NC 4.0) license, which permits others to distribute, remix, adapt, build upon this work non-commercially, and license their derivative works on different terms, provided the original work is properly cited, appropriate credit is given, any changes made indicated, and the use is non-commercial. See: http://creativecommons.org/licenses/by-nc/4.0

\section{REFERENCES}

1. Englard S, Seifter $\mathrm{S}$. The biochemical functions of ascorbic acid. Annu Rev Nutr 1986;6:365-406.

2. May JM, Qu ZC, Meredith ME. Mechanisms of ascorbic acid stimulation of norepinephrine synthesis in neuronal cells. Biochem Biophys Res Commun 2012;426:148-52.

3. Khaw KT, Bingham S, Welch A, et al. Relation between plasma ascorbic acid and mortality in men and women in EPIC-Norfolk prospective study: a prospective population study. European Prospective Investigation into Cancer and Nutrition. Lancet 2001;357:657-63.

4. Loria CM, Klag MJ, Caulfield LE, et al. Vitamin C status and mortality in US adults. Am J Clin Nutr 2000;72:139-45.
5. Nyyssönen K, Parviainen MT, Salonen R, et al. Vitamin C deficiency and risk of myocardial infarction: prospective population study of men from eastern Finland. BMJ 1997;314:634-8.

6. Cook NR, Albert CM, Gaziano JM, et al. A randomized factorial trial of vitamins $C$ and $E$ and beta carotene in the secondary prevention of cardiovascular events in women: results from the Women's Antioxidant Cardiovascular Study. Arch Intern Med 2007;167:1610-8.

7. Heart Protection Study Collaborative Group. MRC/BHF Heart Protection Study of antioxidant vitamin supplementation in 20,536 high-risk individuals: a randomised placebo-controlled trial. Lancet 2002;360:23-33.

8. Hercberg S, Galan P, Preziosi P, et al. The SU.VI.MAX Study: a randomized, placebo-controlled trial of the health effects of antioxidant vitamins and minerals. Arch Intern Med 2004;164:2335-42.

9. Lykkesfeldt J, Poulsen HE. Is vitamin C supplementation beneficial? Lessons learned from randomised controlled trials. Br J Nutr 2010;103:1251-9.

10. Griswold MG, Fullman N, Hawley C, et al. Alcohol use and burden for 195 countries and territories, 1990-2016: a systematic analysis for the Global Burden of Disease Study 2016. The Lancet 2018;392:1015-35.

11. Chaudhry SI, Newell EL, Lewis RR, et al. Scurvy: a forgotten disease. Clin Exp Dermatol 2005;30:735-6.

12. Wang AH, Still C. Old world meets modern: a case report of scurvy. Nutr Clin Pract 2007;22:445-8.

13. Léger D. Scurvy: reemergence of nutritional deficiencies. Can Fam Physician 2008;54:1403-6.

14. Takeshima M, Echizenya M, Inomata $\mathrm{Y}$, et al. Scurvy in an alcoholdependent patient with a severely unbalanced diet. Psychiatry Clin Neurosci 2014;68:242-3.

15. Gião Antunes AS, Peixe B, Guerreiro H. Gastrointestinal bleeding secondary to scurvy in an alcoholic malnourished cirrhotic patient. ACG Case Rep J 2017;4:e29.

16. Lux-Battistelli C, Battistelli D. Latent scurvy with tiredness and leg pain in alcoholics: an underestimated disease three case reports. Medicine 2017;96:e8861.

17. Bennett SE, Schmitt WP, Stanford FC, et al. Case 22-2018: A 64 -year-old man with progressive leg weakness, recurrent falls, and anemia. N Engl J Med 2018;379:282-9.

18. Fain $\mathrm{O}$, Pariés $\mathrm{J}$, Jacquart $\mathrm{B}$, et al. Hypovitaminosis $\mathrm{C}$ in hospitalized patients. Eur J Intern Med 2003;14:419-25.

19. Institute of Medicine \& National Academy of Sciences. Dietary Reference Intakes for Vitamin C, Vitamin E, Selenium and Carotenoids. A Report of the Panel on Dietary Antioxidants and Related Compounds, Subcommittees on Upper Reference Levels of Nutrients and of the Interpretation and Use of Dietary Reference Intakes, and the Standing Committee on the Scientific Evaluation of Dietary Reference Intakes, Food and Nutrition Board. Washington, DC: National Academy Press, 2000.

20. Johnston CS, Corte C. People with marginal vitamin $C$ status are at high risk of developing vitamin C deficiency. J Am Diet Assoc 1999;99:854-6.

21. Baines $M$. Detection and incidence of $B$ and $C$ vitamin deficiency in alcohol-related illness. Ann Clin Biochem 1978;15:307-12.

22. Majumdar SK, Patel S, Shaw GK, et al. Vitamin C utilization status in chronic alcoholic patients after short-term intravenous therapy. Int $J$ Vitam Nutr Res 1981;51:274-8.

23. Sviripa EV. [Vitamin C metabolism in alcoholism and alcoholic psychoses]. Zh Nevropatol Psikhiatr Im S S Korsakova 1971;71:422-5.

24. Sprince H, Parker CM, Smith GG. Article on Ascorbic Acid. Int J Vitam Nutr Res 1977;(Suppl 16):185.

25. Subramanian VS, Srinivasan P, Said HM. Uptake of ascorbic acid by pancreatic acinar cells is negatively impacted by chronic alcohol exposure. Am J Physiol Cell Physiol 2016;311:C129-35.

26. Faizallah R, Morris Al, Krasner N, et al. Alcohol enhances vitamin $\mathrm{C}$ excretion in the urine. Alcohol Alcohol 1986;21:81-4.

27. Susick RL, Zannoni VG. Effect of ascorbic acid on the consequences of acute alcohol consumption in humans. Clin Pharmacol Ther 1987;41:502-9.

28. Chen MF, Boyce HW, Hsu JM. Effect of ascorbic acid on plasma alcohol clearance. J Am Coll Nutr 1990;9:185-9.

29. Li Wenjie, Xin Qiliang, Xin Qiliang, et al. Vitamin C protective role for alcoholic liver disease in mice through regulating iron metabolism. Toxicol Ind Health 2011;27:341-8.

30. World Health Organization. Clinical Guidelines for Withdrawal Management and Treatment of Drug Dependence in Closed Settings. WHO Guidelines Approved by the Guidelines Review Committee. Geneva: WHO Press, 2009. 
31. Soyka M, Kranzler HR, Hesselbrock V, et al. Guidelines for biological treatment of substance use and related disorders, part 1: Alcoholism, first revision. World J Biol Psychiatry 2017;18:86-119.

32. Herbert K, Roger W, Raymond A. Practice Guideline For The Treatment of Patients With Substance Use Disorders. 2nd edn. American Psychiatric Association [Internet], 2006.

33. Center for Substance Abuse Treatment. Detoxification and Substance Abuse Treatment. Treatment Improvement Protocol (TIP) Series 45. DHHS Publication No. (SMA) 06-4131. Rockville, MD: Substance Abuse and Mental Health Services Administration, 2006.

34. Australian Government Department of Health and Ageing. Guidelines for the Treatment of Alcohol Problems. Sydney: Commonwealth of Australia, 2009: 1-232.

35. Drug and Alcohol Services South Australia. Management of patients at risk of alcohol withdrawal in acute hospitals. Adelaide: Government of South Australia Department for Health and Ageing, 2016: 8.

36. National Institute for Health and Clinical Excellence, 2018. Alcoholuse disorders: diagnosis and clinical management of alcohol-related physical complications (CG100). Available from: https://www.nice. org.uk/guidance/CG100 [Accessed 24 Aug 2018]
37. National Health Service. Alcohol Withdrawal Guidelines. Southampton: Southern Health NHS Foundation Trust, 2018: 7-10.

38. National Health Service. Clinical Guideline: Detection of alcohol misusers, management of alcohol withdrawal syndrome and Wernicke's Encephalopathy. 2. London: Guy's and St Thomas' NHS Foundation Trust, 2012.

39. National Health Service. NHS grampian (acute sector) guidance for the prescribing of vitamin and mineral supplements for hospitalized patients with a history of excess alcohol consumption. Aberdeen: NHS Grampian, 2013: 3-6.

40. Teucher B, Olivares M, Cori H. Enhancers of iron absorption: ascorbic acid and other organic acids. Int J Vitam Nutr Res 2004;74:403-19.

41. Flannery AH, Adkins DA, Cook AM. Unpeeling the evidence for the Banana Bag: Evidence-based recommendations for the management of alcohol-associated vitamin and electrolyte deficiencies in the ICU. Crit Care Med 2016;44:1545-52.

42. Baxmann AC, De O G Mendonça C, Heilberg IP. Effect of vitamin C supplements on urinary oxalate and $\mathrm{pH}$ in calcium stone-forming patients. Kidney Int 2003;63:1066-71. 